\title{
ANALISIS KEPATUHAN WAJIB PAJAK ORANG PRIBADI BERKAITAN DENGAN ADANYA KEBIJAKAN PENGHAPUSAN SANKSI PAJAK
}

\author{
Istiqomah \\ Prodi Akuntansi Universitas Negeri Yogyakarta \\ istiqomah.istiqomah.08@gmail.com
}

\begin{abstract}
Abstrak: Analisis Kepatuhan Wajib Pajak Orang Pribadi Berkaitan dengan Adanya Kebijakan Penghapusan Sanksi Pajak. Penelitian ini bertujuan untuk mengetahui kepatuhan WPOP Usaha sebelum dan sesudah berlakunya penghapusan sanksi pajak tahun 2014-2015. Metode pengumpulan data dengan teknik dokumentasi. Teknik analisis data dalam penelitian ini menggunakan rasio kepatuhan wajib pajak pada tahun 2014-2015. Uji statistik menggunakan Uji Beda Sampel Berpasangan (Paried Sample t-Test). Hasil penelitian menunjukkan jumlah kepatuhan WPOP Usaha yang menyampaikan SPT Tahunan tepat waktu mengalami peningkatan dari tahun 2014 sebesar 30,00\% dan tahun 2015 sebesar 32,20\%. Jumlah kepatuhan WPOP Usaha yang menyampaikan SPT Tahunan tidak tepat waktu mengalami peningkatan dari tahun 2014 sebesar 9,00\% dan tahun 2015 sebesar 9,01\%. Jumlah kepatuhan WPOP Usaha yang tidak menyampaikan SPT Tahunan mengalami penurunan dari tahun 2014 sebesar 61,01\% kemudian tahun 2015 sebesar 58,78\%. Hasil Uji Beda Berpasangan (Paried Sample t-Test) tidak terdapat perbedaan antara sebelum dan sesudah berlakunya kebijakan penghapusan pajak, yaitu hasil $t_{\text {hitung }}(-3,295<4,303)$ jadi hasil hipotesis ditolak.
\end{abstract}

Kata kunci: Kepatuhan Wajib Pajak Orang Pribadi, Penghapusan Sanksi Pajak

Abstract: An Analysis of Individual Taxpayer Compliance in Relation oo the Policy on The Elimination of Tax Administrative Sanctions. This study aimed to investigate the compliance of individual taxpayers with business before and after the policy on the elimination of tax administrative sanctions applied in 2014 -2015. The data were collected through documentation. They were analyzed by means of the ratio of taxpayer compliance in 2011-2015. The statistical test was the paired samples t-test. The results of the study showed that the amount of the compliance of individual taxpayers with business submitting annual tax notifications on time increased in 2014 by 30,00\% and in 2015 by $32.20 \%$. The amount of the compliance of individual taxpayers with business submitting annual tax notifications not on time increased in 2014 by 9,00\% and in 2015 by 9.01\%. The amount of the compliance of individual taxpayers with business not submitting annual tax notifications decreased in 2014 by $61.01 \%$ and in 2015 by $58.78 \%$. The results of the paired samples $t$-test showed that there was not has a difference between the compliance before and after the application of the policy on the elimination of tax administrative sanctions, indicated by tobserved $(-3.295<4.303)$, so that the hypothesis was rejected.

Keywords: Compliance of Individual Taxpayers, Elimination of Tax Administrative Sanctions 


\section{PENDAHULUAN}

Secara umum pajak adalah pungutan dari masyarakat oleh negara (pemerintah) berdasarkan undang-undang yang bersifat dapat dipaksakan dan tergantung oleh yang wajib membayarnya dengan tidak mendapatkan prestasi kembali (kontra prestasi/balas jasa) secara langsung, yang hasilnya digunakan untuk membiayai pengeluaran negara dalam penyelenggaraan pemerintah dan pembangunan, Marihot (2013:7). Hal ini menunjukkan bahwa pajak adalah pembayaran wajib pajak yang dikenakan berdasarkan undang-undang yang tidak dapat dihindari bagi yang berkewajiban dan bagi mereka yang tidak mau membayar pajak dapat dilakukan paksaan. Dengan demikian, akan terjamin bahwa kas negara akan selalu berisi uang pajak.

Peraturan perundang-undangan perpajakan selalu mengalami perubahan, tetapi tidak merubah ciri dan corak sistem pemungutan pajak yang berlaku, yaitu sistem self assessment, yang artinya Wajib Pajak (WP) diwajibkan menghitung, memperhitungkan, dan membayar sendiri jumlah pajak yang seharusnya terhutang sesuai dengan ketentuan peraturan perundang-undangan pajak yang berlaku. WP berkewajiban untuk melaporkan secara teratur jumlah pajak yang terhitung dan yang dibayar sebagaimana ditentukan dalam peraturan perundang-undangan yang berlaku. Adanya sistem self assessment diharapkan pelaksanaan administrasi perpajakan akan semakin efisien dan tidak berbelit-belit. Sehingga tugas administrasi perpajakan akan semakin rapi dan terstruktur dengan baik. Sebagai upaya untuk melakukan terobosan khusus dalam menggali potensi pendapatan perpajakan.

Pemerintah secara berkelanjutan mengeluarkan kebijakan dalam rangka penerimaan pajak, baik secara ekstensifikasi maupun intensifikasi. Ekstensifikasi berfokus pada program peningkatan jumlah WP terdaftar. Intensifikasi mengacu pada perluasan objek pajak yang dapat dikenakan. Salah satu kebijakan terbaru pemerintah dibidang perpajakan adalah pelaksanaan penghapusan sanksi pajak. Program menekankan pada aspek penghapusan sanksi administrasi pajak dan diharapkan dapat mendorong WP untuk memenuhi kewajiban perpajakan.

Kebijakan Penghapusan Sanksi Pajak berlaku di tahun 2015. Pemerintah berusaha menyampaikan peraturan kebijakan Penghapusan Sanksi Pajak melalui sosialisasi media masa atau media elektronik. Pemerintah berharap pesan yang disampaikan dapat diterima oleh masyarakat, khususnya WP yang belum 
taat perpajakan. Kenyataannya informasi peraturan Kebijakan Penghapusan Sanksi Pajak tidak sepenuhnya dapat diterima oleh masyarakat. Jumlah WP yang tidak mau membayar atau menyampaikan Surat Pemberitahuan (SPT) Tahunan masih banyak.

Kewajiban perpajakan tidak hanya mendaftarkan diri sebagai WP, tetapi kewajiban perpajakan yaitu menghitung, membayar dan menyampaikan pajaknya. Kewajiban tersebut harus menghitung dan memperhitungkan dengan baik dan benar, kemudian membayar dan menyampaikan SPT tepat waktu. Kewajiban DJP adalah mengawasi kegiatan penelitian, pemeriksaan dan penyidikan tindak pidana agar WP selalu patuh. Upaya untuk terusmenerus mengawasi merupakan potensi untuk mendapatkan kepatuhan WP.

Kepatuhan WP dalam melakukan menyampaikan SPT Tahunan belum sepenuhnya dilaksanakan dengan baik. Kondisi yang menunjukkan bahwa pelaksanaan pemenuhan kewajiban perpajakan dalam hal penyampaian SPT Tahunan adalah masih banyaknya WP yang belum sepenuhnya sadar akan pentingnya menyampaikan SPT Tahunan, masih banyaknya WP yang telah membayarkan pajak tetapi tidak menyampaikan SPT Tahunan. WP beranggapan ketika sudah membayarkan pajak kemudian untuk SPT Tahunan nihil maka tidak perlu lagi menyampaikan SPT Tahunan. Perorangan di Bantul yang terdaftar WP dan terdata di lembaga perpajakan sekitar 90.000 Wajib Pajak. Namun, dari angka tersebut yang melakukan pembayaran pajak sekitar 30.000 .

Daerah Bantul termasuk daerah yang berpotensi berpenghasilan pajak tinggi. Dilihat dari segi pendidikan yang sudah baik. Pendidikan menjadi jembatan antara WP dengan pendapatan pajak. Semakin berpendidikan tinggi maka akan semakin sadar WP yang mengerti pentingnya pajak. Dilihat dari segi pekerjaan juga Daerah Bantul sudah maju, karena kebanyakan dari penduduk Bantul banyak yang bekerja, baik sebagai PNS maupun Swasta. Potensi pendapatan pajak untuk Daerah Bantul sangat tinggi tetapi realisasi yang terjadi sampai tahun 2015 masih dikatakan rendah, mengingat dari jumlah wajib pajak yang berkewajiban membayar dan melaporkan pajaknya. Penerimaan oajak pada tahun 2015 ditargetkan sebesar Rp 750 Miliar. Namun, hingga akhir Desember tercapai sekitar Rp 635 Miliar atau 85\%, (Bisnis.com, 7 Januari 2016)

\section{METODE PENELITIAN}

\section{Jenis Penelitian}

Penelitian ini menggunakan penelitian deskriptif kualitatif, yaitu penelitian yang dilakukan pada kondisi objek yang alamiah tanpa adanya 


\section{JURNAL NOMINAL / VOLUME VI NOMOR 1 / TAHUN 2017}

manipulasi, dimana peneliti sebagai instrumen kunci, Sugiyono (2010:14). Penelitian ini lebih menitikberatkan pada penelitian lapangan, karena penelitian ini dilakukan dengan cara berhubungan langsung dengan objek pnelitian.

\section{Waktu dan Tempat Penelitian}

Penelitian ini dilaksanakan di Kantor Pelayanan Pajak Pratama Bantul. Waktu yang digunakan penelitian yaitu pada bulan Maret - April 2016.

\section{Objek dan Subjek Penelitian}

Subjek dalam penelitian ini adalah Wajib Pajak Orang Pribadi yang Mempunyai Usaha. Objek penelitian ini adalah Kepatuhan Wajib Pajak Orang Pribadi Setelah Berlakunya Kebijakan Penghapusan Sanksi Pajak.

\section{Metode Pengumpulan Data}

Data dalam penelitian ini dikumpulkan dengan teknik dokumentasi dan wawancara. Data yang dibutuhkan meliputi jumlah data WPOP Usaha yang menyampaikan SPT Tahunan dan jumlah WPOP terdaftar di KPP Pratama Bantul tahun 2014 sampai dengan tahun 2015. Peneliti menggunakan wawancara tidak terstruktur, peneliti tidak menggunakan pedoman wawancara atau secara sistematis, pedoman peneliti berupa garisgaris besar permasalahan Kepatuhan WPOP Usaha, permasalah Kebijakan Penghapusan Sanksi Pajak, dan Penyampaian SPT Tahunan.

\section{Teknik Analisis Data}

1. Analisis Kepatuhan Wajib Pajak Sebelum Berlakunya Kebijakan Penghapusan Sanksi Pajak Tahun 2014

a. Rasio Kepatuhan Wajib Pajak Tepat Waktu

Peraturan

Menteri

Keuangan Republik Indonesia No:74/PMK.03/2012 mengatur bahwa Wajib Pajak disebut Wajib Pajak patuh apabila memenuhi beberapa persyaratan, salah satunnya adalah tepat waktu dalam menyampaikan SPT. Wajib Pajak yang patuh adalah Wajib Pajak yang melaksanakan kewajibannya sesuai dengan ketentuan peraturan perundang-undangan perpajakan.

SPT Tahunan WPOP tepat waktu

$\overline{\text { WPOP terdaftar wajib SPT Tahunan }} x 100 \%$

b. Rasio Kepatuhan Wajib Pajak tidak Tepat Waktu

Jumlah SPT Tahunan WPOP yang digunakan dalam perhitungan ini adalah SPT Tahunan WPOP yang tidak tepat waktu yaitu: disampaikan lebih dari tiga bulan setelah akhir Tahun Pajak. Perhitungan ini dilakukan untuk Tahun 2014.

$\frac{\text { SPT Tahunan WPOP tidak tepat waktu }}{\text { WPOP terdaftar wajib SPT Tahunan }} x 100 \%$

c. Rasio Kepatuhan Wajib Pajak tidak Menyampaikan SPT Tahunan 
Jumlah WPOP yang tidak menyampaikan SPT Tahunan dalam perhitungan ini adalah selisih antara jumlah WPOP terdaftar yang wajib SPT Tahunan dengan jumlah seluruh penerimaan SPT Tahunan WPOP selama satu tahun.

\section{SPT Tahunan WPOP tidak melaporkan SPT}

WPOP terdaftar waijb SPT Tahunan $-x 100 \%$

2. Analisis Kepatuhan Wajib Pajak Berkaitan dengan Adanya Kebijakan Penghapusan Sanksi Pajak Tahun 2015

a. Rasio Kepatuhan Wajib Pajak Tepat Waktu

$$
\begin{aligned}
& \text { Peraturan Menteri Keuangan } \\
& \text { Republik Indonesia } \\
& \text { No:74/PMK.03/2012 mengatur } \\
& \text { bahwa Wajib Pajak disebut Wajib } \\
& \text { Pajak patuh apabila memenuhi } \\
& \frac{\text { SPT Tahunan WPOP tepat waktu }}{\text { WPOP terdaftar wajib SPT Tahunan }} x 100 \%
\end{aligned}
$$

b. Rasio Kepatuhan Wajib Pajak tidak Tepat Waktu

Jumlah SPT Tahunan WPOP yang digunakan dalam perhitungan ini adalah SPT Tahunan WPOP yang tidak tepat waktu yaitu: disampaikan lebih dari tiga bulan setelah akhir Tahun Pajak. Perhitungan ini dilakukan untuk Tahun 2015.

SPT Tahunan WPOP tidak tepat waktu WPOP terdaftar wajib SPT Tahunan $x 100 \%$

c. Rasio Kepatuhan Wajib Pajak tidak Menyampaikan SPT Tahunan

Jumlah WPOP yang tidak menyampaikan SPT Tahunan dalam perhitungan ini adalah selisih antara jumlah WPOP terdaftar yang wajib SPT Tahunan dengan jumlah seluruh penerimaan SPT Tahunan WPOP selama satu tahun.

\section{$\frac{\text { SPT Tahunan WPOP tidak melaporkan SPT }}{\text { WPOP terdaftar wajib SPT Tahunan }} \times 100 \%$}

3. Uji Beda Sampel Berpasangan (Paired Sampel t-Test)

Paried Sampel t-Test digunakan untuk menguji dua sampel yang berpasangan, apakah keduanya mempunyai rata-rata yang secara nyata berbeda atau tidak.

Hipotesis :Terdapat perbedaan antara kepatuhan wajib WPOP Usaha berkaitan dengan adanaya kebijakan penghapusan sanksi pajak.

Menentukan kriteria pengujian Ho diterima apabila t_tabel>t_hitung 
Ho ditolak apabila $t \_h i t u n g \leq t \_t a b e l$

\section{HASIL PENELITIAN DAN PEMBAHASAN}

Tabel 3. Jumlah WPOP Usaha yang menyampaikan SPT Tahunan Tahun 20142015

\begin{tabular}{|c|c|c|}
\hline \multirow[t]{2}{*}{ Bulan } & \multicolumn{2}{|c|}{ Tahun } \\
\hline & 2014 & 2015 \\
\hline Januari & 232 & 312 \\
\hline Februari & 527 & 780 \\
\hline Maret & 1.348 & 1.509 \\
\hline April & 342 & 375 \\
\hline Mei & 75 & 65 \\
\hline Juni & 62 & 12 \\
\hline Juli & 37 & 24 \\
\hline Agustus & 54 & 31 \\
\hline \multirow[t]{2}{*}{ Bulan } & \multicolumn{2}{|c|}{ Tahun } \\
\hline & 2014 & 2015 \\
\hline September & 15 & 75 \\
\hline Okrober & 18 & 51 \\
\hline November & 20 & 75 \\
\hline Desember & 9 & 20 \\
\hline Jumlah & 2.739 & 3.329 \\
\hline
\end{tabular}

Sumber: Seksi Pengolahan Data dan Informasi KPP Pratama Bantul

Tabel 4. Jumlah WPOP Usaha yang Menyampaikan SPT Tahunan Tepat Waktu, tidak Tepat Waktu dan tidak Melapor

\begin{tabular}{ccclc}
\hline Tahun & $\begin{array}{c}\text { Tepat } \\
\text { Waktu }\end{array}$ & $\begin{array}{l}\text { Tidak } \\
\text { Tepat } \\
\text { Waktu }\end{array}$ & $\begin{array}{l}\text { Tidak } \\
\text { Melaporka } \\
\text { n }\end{array}$ & $\begin{array}{l}\text { Jumlah } \\
\text { WPOP } \\
\text { Usaha } \\
\text { Terdaftar }\end{array}$ \\
\hline $\mathbf{2 0 1 4}$ & 2.107 & 632 & 4.285 & 7.024 \\
\hline $\mathbf{2 0 1 5}$ & 2.601 & 728 & 4.748 & 8.077
\end{tabular}

Sumber : Seksi Pengolahan Data dan Informasi KPP Pratama Bantul
Analisis Kepatuhan Wajib Pajak

Berkaitan dengan Adanya Kebijakan

Penghapusan Sanksi Pajak Tahun 2014

Rasio Kepatuhan Wajib Pajak Tepat

Waktu

Tabel 5. Jumlah WPOP Usaha yang Menyampaikan SPT Tahuanan Tepat Waktu Tahun 2014

\begin{tabular}{lll}
\hline \multicolumn{1}{c}{ Bulan } & \multicolumn{1}{c}{$\begin{array}{c}\text { WPOP } \\
\text { Tepat Waktu }\end{array}$} & $\begin{array}{c}\text { Rasio } \\
\text { \% }\end{array}$ \\
\hline Januari & 232 & 3,30 \\
\hline Februari & 527 & 7,50 \\
\hline Maret & 1.348 & 19,19 \\
\hline Jumlah & 2.107 & 30,00
\end{tabular}

Sumber: Data Diolah

Hasil hitung tabel diatas menunjukkan bahwa rasio kepatuhan WP yang menyampaikan SPT tepat waktu mengalami perubahan. Rasio kepatuhan WP yang melaporkan SPT Tahunan tepat waktu mengalami peningkatan sebanding dengan pertambahan jumlah WPOP Usaha yang terdaftar pada Kantor Pelayanan Pajak Pratama Bantul. Jumlah WPOP Usaha tepat waktu sebelum berlakunya penghapusan sanksi pajak tahun 2014 sebanyak 2.107 dengan rasio kepatuhan WP sebesar 30,00\%. Rasio Kepatuhan WP paling tinggi sebesar $19,19 \%$ pada bulan Maret. 
Rasio Kepatuhan Wajib Pajak tidak tepat

Waktu

Tabel 6. Jumlah WPOP Usaha yang Menyampaikan SPT Tahunan tidak Tepat Waktu Tahun 2014

\begin{tabular}{lll}
\hline Bulan & $\begin{array}{l}\text { WPOP tidak } \\
\text { Tepat Waktu }\end{array}$ & $\begin{array}{l}\text { Rasio } \\
\text { \% }\end{array}$ \\
\hline April & 342 & 4,87 \\
\hline Mei & 75 & 1,07 \\
\hline Juni & 62 & 0,88 \\
\hline Juli & 37 & 0,53 \\
\hline Agustus & 54 & 0,77 \\
\hline September & 15 & 0,21 \\
\hline Okrober & 18 & 0,26 \\
\hline November & 20 & 0,28 \\
\hline Desember & 9 & 0,13 \\
\hline \multicolumn{1}{c}{ Jumlah } & $\mathbf{6 3 2}$ & $\mathbf{9 , 0 0}$ \\
\hline
\end{tabular}

Sumer : Data Diolah

Hasil perhitungan tabel menunjukkan bahwa rasio kepatuhan WP yang tidak tepat waktu menyampaikan SPT Tahunan tahun 2014 selalu mengalami perubahan. Jumlah WPOP Usaha tidak tepat waktu sebelum berlakunya penghapusan sanksi pajak tahun 2014 sebanyak 632 dengan rasio kepatuhan WP sebesar 9,00\%. Rasio Kepatuhan WP paling tinggi sebesar 4,87\% pada bulan Maret.

Rasio Kepatuhan Wajib Pajak tidak Menyampaikan SPT Tahunan
Tabel 7. Jumlah WPOP Usaha yang tidak menyampaikan SPT Tahunan Tahun 2014

\begin{tabular}{llll}
\hline Tahun & $\begin{array}{l}\text { WPOP } \\
\text { Terdaftar }\end{array}$ & $\begin{array}{c}\text { WPOP } \\
\text { tidak } \\
\text { Melapork } \\
\text { an }\end{array}$ & $\begin{array}{l}\text { Rasio } \\
\text { \% }\end{array}$ \\
& & & \\
\hline $\mathbf{2 0 1 4}$ & 7.024 & 4.285 & 61,01 \\
\hline
\end{tabular}

Sumber: Data Diolah

Hasil perhitungan tabel diatas menunjukkan bahwa jumlah WPOP Usaha yang tidak menyampaikan SPT Tahunan sebanyak 4.285 dengan persentase rasio kepatuhan WP sebesar $61,01 \%$.

Analisis Kepatuhan Wajib Pajak Berkaitan dengan Adanya Kebijakan Penghapusan Sanksi Pajak Tahun 2015

Rasio Kepatuhan Wajib Pajak Tepat Waktu

Tabel 5. Jumlah WPOP Usaha yang Menyampaikan SPT Tahuanan Tepat Waktu Tahun 2014

\begin{tabular}{lll}
\hline Bulan & $\begin{array}{l}\text { WPOP } \\
\text { Waktu }\end{array}$ & $\begin{array}{l}\text { Rasio } \\
\boldsymbol{\%}\end{array}$ \\
\hline Januari & 312 & 3,86 \\
\hline Februari & 780 & 9,66 \\
\hline Maret & 1.509 & 18,68 \\
\hline Jumlah & 2.601 & 32,20
\end{tabular}

Sumber: Data Diolah

Hasil hitung tabel diatas menunjukkan bahwa rasio kepatuhan WP yang menyampaikan SPT tepat waktu mengalami perubahan. Rasio kepatuhan WP yang melaporkan SPT Tahunan tepat waktu mengalami peningkatan sebanding dengan pertambahan jumlah WPOP Usaha yang terdaftar pada Kantor Pelayanan Pajak Pratama Bantul. Jumlah WPOP Usaha tepat waktu sebelum berlakunya 
penghapusan sanksi pajak tahun 2014 sebanyak 2.107 dengan rasio kepatuhan WP sebesar 32,20\%. Rasio Kepatuhan WP paling tinggi sebesar $18,68 \%$ pada bulan Maret.

Rasio Kepatuhan Wajib Pajak tidak tepat Waktu

Tabel 6. Jumlah WPOP Usaha yang Menyampaikan SPT Tahunan tidak Tepat Waktu Tahun 2015

\begin{tabular}{lll}
\hline Bulan & $\begin{array}{l}\text { WPOP tidak } \\
\text { Tepat Waktu }\end{array}$ & Rasio \% \\
\hline April & 375 & 4,64 \\
\hline Mei & 65 & 0,80 \\
\hline Juni & 12 & 0,15 \\
\hline Juli & 24 & 0,30 \\
\hline Agustus & 31 & 0,38 \\
\hline September & 75 & 0,93 \\
\hline Okrober & 51 & 0,63 \\
\hline November & 75 & 0,93 \\
\hline Desember & 20 & 0,25 \\
\hline Jumlah & $\mathbf{7 2 8}$ & $\mathbf{9 , 0 1}$ \\
\hline
\end{tabular}

\section{Sumer : Data Diolah}

Hasil perhitungan tabel menunjukkan bahwa rasio kepatuhan WP yang tidak tepat waktu menyampaikan SPT Tahunan tahun 2014 selalu mengalami perubahan. Jumlah WPOP Usaha tidak tepat waktu sebelum berlakunya penghapusan sanksi pajak tahun 2014 sebanyak 632 dengan rasio kepatuhan WP sebesar 9,01\%. Rasio Kepatuhan WP paling tinggi sebesar 4,64\% pada bulan Maret.

Rasio Kepatuhan Wajib Pajak tidak Menyampaikan SPT Tahunan
Tabel 7. Jumlah WPOP Usaha yang tidak menyampaikan SPT Tahunan Tahun 2015

\begin{tabular}{llll}
\hline Tahun & $\begin{array}{l}\text { WPOP } \\
\text { Terdaftar }\end{array}$ & $\begin{array}{l}\text { WPOP } \\
\text { tidak } \\
\text { Melapork } \\
\text { an }\end{array}$ & $\begin{array}{l}\text { Rasio } \\
\%\end{array}$ \\
\hline $\mathbf{2 0 1 4}$ & 8.077 & 4.748 & 58,78
\end{tabular}

\section{Sumber: Data Diolah}

Hasil perhitungan tabel diatas menunjukkan bahwa jumlah WPOP Usaha yang tidak menyampaikan SPT Tahunan sebanyak 4.748 dengan persentase rasio kepatuhan WP sebesar 58,78\%.

Uji Beda Sampel Berpasangan (Paired Sampel t-Test)

Tabel 11. Output Paried Sampel t-Test

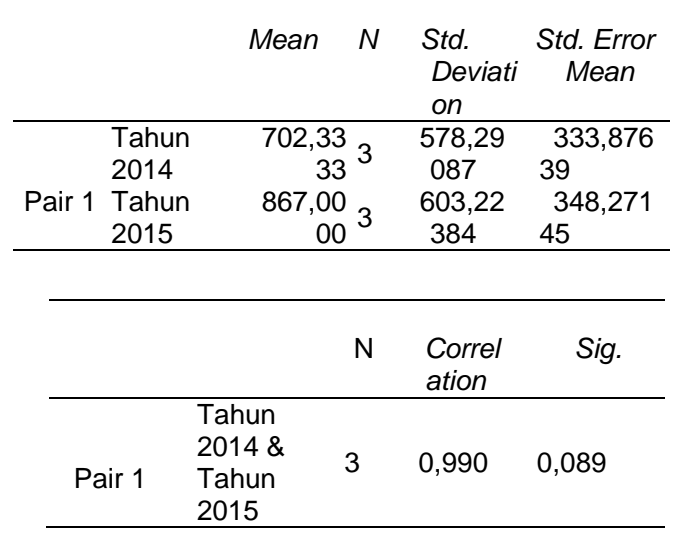

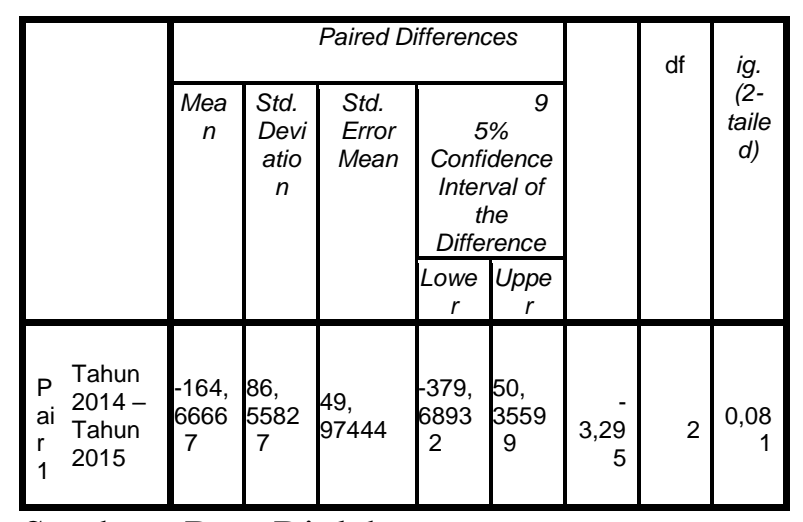

Sumber : Data Diolah

Hasil tabel diatas menunjukkan nilai t_hitung=-3,295<4303 sehingga penelitian ini tidak berhasil atau ditolak. 


\section{JURNAL NOMINAL / VOLUME VI NOMOR 1 / TAHUN 2017}

Hal ini berarti bahwa tidak terdapat perbedaan antara kepatuhan WPOP Usaha yang menyampaikan SPT Tahunan antara sebelum dan sesudah berlakunya kebijakan penghapusan sanksi pajak di Kantor Pelayan Pajak Pratama Bantul.

\section{Pembahasan}

Hasil pengujian hipotesis menggunakan Uji Statistik Beda Sampel Berpasangan tidak terdapat perbedaan antara WPOP Usaha sebelum dan sesudah berlakunya kebijakan penghapusan sanksi pajak Tahun 2014-2015 pada Kantor Pelayanan Pajak Pratama Bantul. Hasil yang diperoleh dari t_hitung sebesar 3,295 dengan ketentuan t_tabel sebesar 4,303 sehingga diperoleh t_hitung lebih kecil dari t_tabel dan hasil hipotesis ditolak.

DJP mengeluarkan kebijakan baru berupa kebijakan penghapusan sanksi pajak dengan tujuan untuk meningkatkan pelayanan kepada WP baik WPOP maupun WP Badan dalam melaksanakan kewajiban perpajakan. Salah satu kewajiban WP adalah menyampaikan SPT Tahunan sebelum jatuh tempo yang telah ditentukan. Kebijakan penghapusan sanksi pajak memberikan keuntungan kepada WP yang belum aktif serta WP yang belum tepat dalam melaporankan pajak ditahun sebelumnya. Sanksi bunga sebesar 2\% (dua persen) atau denda penyampaian SPT Tahunan akan dihapuskan di tagihan WP

yang melakukan pelangaran. Peraturan penghapusan sanksi pajak berlaku 1 (satu) tahun, yaitu tahun 2015. Sehingga disayangkan ketika WP yang belum benar dalam melaporkan pajak atau WP yang belum aktif tidak memanfaatkan peraturan tersebut.

Hasil penelitian ini menunjukkan bahwa penerapan kebijakan penhapusan sanksi pajak belum berhasil menjadi solusi untuk meningkatkan kepatuahan WPOP khususnya WPOP Usaha. Kemudahankemudahan yang diberikan DJP ternyata belum mampu meningkatkan kepatuhan WPOP Usaha yang menyampaikan SPT Tahunan tepat waktu. Dibuktikan dari hasil uji beda sampel berpasangan antar sebelum dan sesudah berlakunya kebijakan penghapusan sanksi pajak.

Salah satu faktor yang mempengaruhi kebijakan penghapusan sanksi pajak belum berhasil untuk daerah Bantul yaitu kesadaran Wajib Pajak. Menurut Kepala Seksi Pengolahan Data dan Informasi ada sebagian WP yang telah membayarkan pajak, tetapi WP tidak menyampaikan SPT Tahunan. Sedikit atau banyak WP yang telah membayar pajak dan tidak menyampaikan SPT Tahunan, tetap akan mengurangi jumlah kepatuhan WPOP Usaha pada Kantor Pelayanan Pajak Pratama Bantul. Kriteria WP dikatakan patuh yaitu WP yang 


\section{JURNAL NOMINAL / VOLUME VI NOMOR 1 / TAHUN 2017}

menghitung, membayar, dan menyampaikan SPT tepat waktu.

\section{SIMPULAN DAN SARAN}

\section{Simpulan}

a. Jumlah WPOP Usaha yang melaporkan SPT Tahunan tepat waktu setelah berlakunya kebijakan penghapusan sanksi pajak bertambah sebanyak 494, dari tahun 2014 diperoleh 2.107 dan ditahun 2015 sebanyak 2.601. Rasio kepatuhan WPOP Usaha tepat waktu setelah berlakunya penghapusan sanksi pajak meningkat sebesar 2,20\%, pada tahun 2014 sebesar $30,00 \%$ dan tahun 2015 sebesar 32,20\%.

b. Jumlah WPOP Usaha yang melaporkan SPT Tahunan tidak tepat waktu setelah adanya kebijakan penghapusan sanksi pajak bertambah sebanyak 96, yaitu tahun 2014 sebanyak 632 dan di tahun 2015 sebesar 728. Hasil rasio kepatuhan WPOP Usaha tidak tepat waktu setelah berlakunya kebijakan penghapusan sanksi pajak meningkat sebesar $0,01 \%$ yaitu tahun 2014 sebesar 9,00\% dan tahun 2015 sebesar $9,01 \%$.

c. Jumlah WPOP Usaha yang tidak melaporkan SPT Tahunan setelah adanya kebijakan penghapusan sanksi pajak bertambah sebanyak 463, yaitu diperoleh hasil untuk tahun 2014 sebanyak 4.285 dan tahun 2015 sebanyak 4.748. Tetapi untuk rasio kepatuhan wajib pajak dikatakan menurun sebesar 2,23\%, yaitu tahun 2014 sebesar $61,01 \%$ dan tahun 2015 sebesar $58,78 \%$. Hasil yang diperoleh dari rasio kepatuhan wajib pajak kebijakan penghapusan sanksi pajak berhasil meningkatkan WPOP Usaha untuk aktif kembali sebagai wajib pajak, dimana wajib pajak harus melaporkan, membayarkan kemudian melaporkan SPT Tahunan.

d. Hasil statistik menggunakan uji beda berpasangan dapat disimpulkan bahwa tidak terdapat perbedaan antara sebelum dan sesudah berlakunya kebijakan penghapusan sanksi pajak di Kantor Pelayanan Perpajakan Pratama Bantul. Hal ini ditunjukkan dari hasil pengujian hipotesis menggunakan Paired Sample tTest yang diperoleh nilai dari $t_{p}$ sebesar -3,295 dengan ketentuan sebesar 4,303 sehingga diperoleh $t_{p}$ lebih kecil dari $\quad$ dan hasil hipotesis ditolak. Berarti Direktorat Jenderal Pajak belum berhasil meningkatkan kepatuhan WPOP Usaha melalui peraturan kebijakan penghapusan sanksi pajak.

\section{Saran}

a. Direktorat Jendral Pajak harus selalu memberikan sosialisasi kepada masyarakat akan pentingnya melaporkan pajak. Sosialisasi paling efektif dilakukan dengan eksekusi atau mendatangi warga Bantul yang telah mempunyai usaha sendiri, tanpa memperhatikan besar kecilnya usaha yang 
dimiliki karena banyak sekali UMKM di Bantul yang belum terdaftar sebagai wajib pajak.

b. Setiap Wajib Pajak baru yang telah mendaftarkan diri langsung diberikan penjelasan mengenai hak dan kewajiban sebagai Wajib Pajak, tidak hanya dalam bentuk $\mathrm{CD}$ atau hard-copy tetapi harus diberikan penjelasan secara lisan. Agar Wajib Pajak memahami betul peran sebagai Wajib Pajak yang patuh sesuai dengan UU perpajakan.

c. Aparatur perpajakan harus mengawasi wajib pajak ketika wajib pajak mulai lalai dalam membayarkan maupun melaporkan pajakanya, dengan cara selalu memberikan peringatan kepada wajib pajak yang telat dalam membayar ataupun menyampaikan SPT Tahunan. Surat teguran, sebaiknya segera sesudah WP lalai tanpa harus menunggu tahun-tahun berikutnya.

\section{DAFTAR PUSTAKA}

Abdul, Rahman. (2010). Administrasi Perpajakan. Bandung : Nuansa.

Herry, Purwono. (2010). Dasar-dasar Perpajakan dan Akuntansi Pajak. Jakarta: Erlangga.

Eprints. "Bab II kajian Teori". Artikel. Diunduh dari http://eprints.uny.ac.id/7889/3/BAB \%202-09409134015.pdf pada hari Sabtu, 31 Oktober 2015.

Erly, Suandy. (2013). Hukum Pajak. Jakarta: Salemba Empat.
Ida, Zuraida, dan L., Y., Hari Sih Advianto. (2011). Penagihan Pajak. Bogor : Ghalia Indonesia.

Imam, Ghozali. (2011). Aplikasi Analisis Multivariate dengan Program IBM SPSS 19. Semarang:Undip.

Incuna, Surawijaya. (2015). "Pengurangan atau Penghapusan Sanksi Administrasi Tahun 2015" Artikel. Diunduh dari pajaktaxes.blogspot.com/2015/05/pe ngurangan-atau-penghapusansanksi.html?m=1 pada hari Senin, 19 Oktober 2015.

Jonathan, Sarwono. (2006). Metode Penelitian Kuantitatif dan Kualitatif. Yogyakarta:Graha Ilmu.

Liberti, Pandiangan. (2014). Administrasi Perpajakan. Jakarta: Erlangga

Mardiasmo. (2011). Perpajakan. Yogyakarta: Andi Offset.

Rimsky, K. Judisseno. (2005). Pajak dan Strategi Bisnis. Jakarta : Gramedia Pustaka Utama.

Robinson, Taligan. (2008). Perencanaan Pembangunan Wilayah. Jakarta: Sinar Grafika Offser.

Pahala, Marihot, Siahaan. (2013). Pajak Daerah dan Retribusi Daerah. Jakarta: Rajawali Pers.

Siti, M., Haris, W. dan Intan, Immanuel. (2014) Faktor yang Mempengaruhi Kemauan Untuk Membayar Pajak Orang Pribadi yang Melakukan Pekerjaan Bebas (Studi pada KPP pratama Kota Madiun). Jurnal.

Siti, Resmi. (2011). Perpajakan. Jakarta : Salemba Empat. 
Sugiyono. (2010). Metode Penelitian Bisnis. Bandung: Alfabeta.

Suwanto, Dian, Pranoto. (2015). "Pengurangan atau Penghapusan Sanksi Administrasi Tahun 2015". Artikel. Diunduh dari http://www.jtanzilco.com/blog/detail /137/slug/pengurangan-ataupenghapusan-sanksi-administrasitahun-2015-tax-amnesty pada hari Kamis, 29 Oktober 2015.

Wikipedia. (2013). "Kepatuhan”. Artikel. Diunduh dari https://id.wikipedia.org/wiki/Kepatu han pada hari Kamis, 29 Oktober 2015.

Yustinus, Prastowo, et al. (2011). Buku Pintar Menghitung Pajak. Jakarta:Raih Asa Sukses. 